\title{
Knowledge, awareness and attitude about prenatal sex determination, pre-conception and pre-natal diagnostic techniques act among pregnant women in the South Indian union territory of Puducherry
}

\author{
Vijayan Sharmila, Thirunavukkarasu Arun Babu*, Darendra Singh
}

Department of Obstetrics and Gynecology, Indira Gandhi Medical College and Research Institute, Puducherry, India

Received: 28 July 2016

Accepted: 28 August 2016

\section{*Correspondence:}

Dr. Thirunavukkarasu Arun Babu,

E-mail: babuarun@yahoo.com

Copyright: (c) the author(s), publisher and licensee Medip Academy. This is an open-access article distributed under the terms of the Creative Commons Attribution Non-Commercial License, which permits unrestricted non-commercial use, distribution, and reproduction in any medium, provided the original work is properly cited.

\begin{abstract}
Background: This study was conducted among pregnant women in the Union territory Puducherry, South India with the aim of studying their Knowledge, awareness and attitude regarding prenatal sex determination and Pre-Natal Diagnostic Techniques Act (PCPNDT) Act.

Methods: The present cross-sectional study was conducted on 160 consenting pregnant women selected using convenience sampling, attending the antenatal Out Patient Department of our hospital. The data was collected using a pre-tested semi-structured questionnaire consisting of 4 sections, Section 1: Participants general information, section 2: Awareness about pre-natal sex determination, Section 3: Awareness on the PCPNDT Act, Section 4: Attitude towards prenatal sex determination.

Results: Out of a total 160 pregnant women who filled the questionnaire, 128 participants returned completed questionnaire which was used for analysis. Media was the main source of information (66.4\%) followed by friends and relatives $(22.66 \%)$ and health care personnel (10.94\%). Ultrasonography, as a method of sex determination was known to $87.5 \%$ of pregnant women. Sixty eight percentage of participants were aware of a government act for prevention of sex determination and $84.3 \%$ knew that prenatal sex determination is a punishable offence. Seventy one percent participants knew both patients and the doctors are punishable if involved. Eight one percentage participants were willing to educate people about PCPNDT Act.

Conclusions: Though higher proportion of our study participants knew about the prenatal sex determination, they were not fully aware of the punishment for prenatal sex determination. Pregnant women have to be educated about the penalization for violation of the Act and ethical issues related with female sex selective abortion and feticide. Similar studies in other settings on a larger sample size should be done for in depth understanding of this issue.
\end{abstract}

Keywords: PCPNDT Act, Pre-natal, Sex determination, Pregnancy, Women

\section{INTRODUCTION}

Sex ratio is an important social indicator of prevailing equity between males and females in the society. It is defined as the number of females per thousand males. ${ }^{1}$ Changes in sex ratio reflect underlying socioeconomic and cultural patterns. Sex ratio in India has been in the decline for the past few decades. ${ }^{2}$ It has been estimated at 933 during the census conducted in 2011. ${ }^{3}$ Various factors that have been attributed to the decline in sexratio include sex differentials in mortality, sex selective migration and sex ratio at birth. ${ }^{4}$

Birth of a female child in India, is perceived by many as a curse with economic and social liability. ${ }^{2}$ Usage of modern ultrasound for pre-natal sex determination has led to female sex selective abortions contributing to the decline in female sex ratio. The business of pre-natal sex 
selection and abortions in India has an estimated turnover of several hundred crores with numerous sonography centres spread all over the country. ${ }^{5}$ The government of India introduced the pre-natal diagnostic techniques act (PNDT) in 1994 that was later amended as preconception and pre-natal diagnostic techniques act (PCPNDT) in 2002. The objective of the act was to prevent the misuse of diagnostic techniques in sex selection and sex selective abortions. ${ }^{6}$ Violation of this act can lead to a fine of Rs.10,000 and up to three years imprisonment for a first offence, with greater fines and longer terms of imprisonment for repeat offenders. ${ }^{7}$ Mass media was used to spread awareness among the public on this issue. However, all these measures have met with limited success to achieve the desired results with no apparent improvement in the sex ratio. ${ }^{8}$ The present study was conducted among pregnant women in the Union territory Puducherry, South India with the aim of studying their knowledge, awareness and attitude regarding prenatal sex determination and PCPNDT Act.

\section{METHODS}

The present cross-sectional study was conducted at Indira Gandhi Medical College and Research Institute in Puducherry, India. The study population included pregnant women attending the antenatal outpatient department. A total of 160 pregnant women who consented for the study were selected using convenience sampling. The data was collected using a pre-tested semistructured questionnaire consisting of 4 sections (section 1: participants general information, section 2: awareness about pre-natal sex determination, section 3: awareness on the PCPNDT Act, section 4: attitude towards prenatal sex determination). Participant's identity and the collected information were kept confidential. Data were entered in MS Excel and analyzed using Statistical Package of Social Sciences (SPSS) 16.0.

\section{RESULTS}

A total of 160 pregnant women were assessed for their knowledge, awareness and attitude regarding prenatal sex determination and PCPNDT Act using a pre tested questionnaire. Completed questionnaire returned by 128 participants were used for analysis of data.

The summary of demographic data is tabulated in Table 1. The age of the participants ranged between 18 to 37 years with the mean age of 26 years. Most participants were in the age group of 20-30 years $(n=101,78.9 \%)$. None of the participants were illiterate and $82.03 \%$ had completed higher secondary education or above. Majority of the study participants were housewives $(n=92,71.8 \%)$.

Table 2 shows awareness of the study participants towards prenatal sex determination. $82.03 \% \quad(n=105)$ knew that prenatal sex determination was possible and $16.4 \%(n=21)$ of participants were not aware of such sex determination.
Table 1: Summary of demographic factors.

\begin{tabular}{|c|c|c|}
\hline \multicolumn{2}{|l|}{ Factors } & $\begin{array}{l}\text { Number } \\
\text { (Percentage) }\end{array}$ \\
\hline \multirow{3}{*}{$\begin{array}{l}\text { Age } \\
\text { (in years) }\end{array}$} & $<20$ & $3(2.34 \%)$ \\
\hline & $20-30$ & $101(78.91 \%)$ \\
\hline & $>30$ & $24(18.75 \%)$ \\
\hline \multirow{4}{*}{ Education } & Illiterate & $0(0 \%)$ \\
\hline & 1 st to $4^{\text {th }}$ Class & $2(1.56 \%)$ \\
\hline & 5th To $10^{\text {th }}$ Class & $21(16.41 \%)$ \\
\hline & $\begin{array}{l}\text { Higher secondary } \\
\text { Education or above }\end{array}$ & $105(82.03 \%)$ \\
\hline \multirow{5}{*}{$\begin{array}{l}\text { Socio } \\
\text { economic } \\
\text { status }\end{array}$} & Lower & $0(0 \%)$ \\
\hline & Upper lower & $6(4.69 \%)$ \\
\hline & Lower middle & $34(26.56 \%)$ \\
\hline & Upper middle & $73(57.03 \%)$ \\
\hline & Upper & $15(11.72 \%)$ \\
\hline \multirow{2}{*}{ Occupation } & House wife & $92(71.88 \%)$ \\
\hline & Employed & $36(28.13 \%)$ \\
\hline \multirow{2}{*}{ Parity } & Primi & $70(54.69 \%)$ \\
\hline & Multi & $58(45.31 \%)$ \\
\hline
\end{tabular}

Table 2: Awareness about sex determination among participants.

\begin{tabular}{|c|c|c|}
\hline Question & Response & $\begin{array}{l}\text { Number } \\
\text { (Percentage) }\end{array}$ \\
\hline \multirow{3}{*}{$\begin{array}{l}\text { Is it possible to } \\
\text { do prenatal sex } \\
\text { determination? }\end{array}$} & Yes & $105(82.03 \%)$ \\
\hline & No & $21(16.4 \%)$ \\
\hline & Don't know & $2(1.56 \%)$ \\
\hline \multirow{4}{*}{$\begin{array}{l}\text { Source of } \\
\text { Information }\end{array}$} & $\begin{array}{l}\text { Friends and } \\
\text { relatives }\end{array}$ & $29(22.66 \%)$ \\
\hline & Media & $85(66.41 \%)$ \\
\hline & $\begin{array}{l}\text { Health care } \\
\text { personnel }\end{array}$ & $14(10.94 \%)$ \\
\hline & Others & $0 \%$ \\
\hline \multirow{3}{*}{$\begin{array}{l}\text { Technique used } \\
\text { for Sex } \\
\text { determination }\end{array}$} & Ultrasound & $112(87.50 \%)$ \\
\hline & Others & $14(10.94 \%)$ \\
\hline & Don't know & $2(1.56 \%)$ \\
\hline \multirow{4}{*}{$\begin{array}{l}\text { Place where sex } \\
\text { determination } \\
\text { can be done }\end{array}$} & Private only & $104(81.25 \%)$ \\
\hline & Govt only & $4(3.13 \%)$ \\
\hline & Both & $14(10.94 \%)$ \\
\hline & Don't know & $4(3.13 \%)$ \\
\hline
\end{tabular}

Media was the main source of information $(n=85,66.4 \%)$ followed by friends and relatives $(n=29,22.66 \%)$ and health care personnel $(n=14,10.94 \%)$. When participants were asked regarding the possible methods for sex determination, $87.5 \%(n=112)$ of the pregnant women knew that ultrasonography was the method of sex determination. Majority of the study participants $(n=104$, $81.25 \%$ ) opined that sex determination can be done in private set-ups only. Table 3 shows the awareness of the participants regarding the prenatal diagnostic technique Act (PCPNDT Act). 
Table 3: Awareness regarding PCPNDT act.

\begin{tabular}{|c|c|c|}
\hline Question & Response & Number (\%) \\
\hline \multirow{3}{*}{$\begin{array}{l}\text { Are you aware of a } \\
\text { govt act against sex } \\
\text { determination? }\end{array}$} & Yes & $87(67.97 \%)$ \\
\hline & No & $14(10.94 \%)$ \\
\hline & Don't know & $27(21.09 \%)$ \\
\hline \multirow{3}{*}{$\begin{array}{l}\text { Are you aware that } \\
\text { pre-natal sex } \\
\text { determination is } \\
\text { punishable? }\end{array}$} & Yes & $108(84.38 \%)$ \\
\hline & No & $17(13.28 \%)$ \\
\hline & Don't know & $3(2.34 \%)$ \\
\hline \multirow{3}{*}{$\begin{array}{l}\text { Who can be } \\
\text { punished? }\end{array}$} & Doctor & $5(3.91 \%)$ \\
\hline & Patient & $25(19.53 \%)$ \\
\hline & Both & $92(71.88 \%)$ \\
\hline \multirow{4}{*}{$\begin{array}{l}\text { Punishment for } \\
\text { doctors? }\end{array}$} & Imprisonment & $9(7.03 \%)$ \\
\hline & Fine & $78(60.94 \%)$ \\
\hline & Both & $25(19.53 \%)$ \\
\hline & Don't know & $16(12.50 \%)$ \\
\hline \multirow{4}{*}{$\begin{array}{l}\text { Punishment for } \\
\text { patients? }\end{array}$} & Imprisonment & $9(7.03 \%)$ \\
\hline & Fine & $80(62.50 \%)$ \\
\hline & Both & $20(15.63 \%)$ \\
\hline & Don't know & $19(14.84 \%)$ \\
\hline
\end{tabular}

Table 4: Attitude of the patients towards PCPNDT act.

\begin{tabular}{|c|c|c|}
\hline Question & Response & Number (\%) \\
\hline \multirow{3}{*}{$\begin{array}{l}\text { Would you like to } \\
\text { know sex of your } \\
\text { child? }\end{array}$} & Yes & $102(79.69 \%)$ \\
\hline & No & $17(13.28 \%)$ \\
\hline & No comments & $9(7.03 \%)$ \\
\hline \multirow{4}{*}{$\begin{array}{l}\text { Which child do you } \\
\text { prefer to deliver? }\end{array}$} & Male & $71(55.47 \%)$ \\
\hline & Female & $48(37.50 \%)$ \\
\hline & Either & $9(7.03 \%)$ \\
\hline & No comments & $0(0 \%)$ \\
\hline \multirow{3}{*}{$\begin{array}{l}\text { Would you } \\
\text { terminate if it is a } \\
\text { female fetus? }\end{array}$} & Yes & $2(1.56 \%)$ \\
\hline & No & $90(70.31 \%)$ \\
\hline & No comments & $36(28.13 \%)$ \\
\hline \multirow{3}{*}{$\begin{array}{l}\text { Do you think pre- } \\
\text { natal sex } \\
\text { determination is } \\
\text { right? }\end{array}$} & Yes & $85(66.41 \%)$ \\
\hline & No & $25(19.53 \%)$ \\
\hline & No comments & $18(14.06 \%)$ \\
\hline \multirow{3}{*}{$\begin{array}{l}\text { Should pre-natal } \\
\text { sex determination } \\
\text { be punishable? }\end{array}$} & Yes & $25(19.53 \%)$ \\
\hline & No & $82(64.06 \%)$ \\
\hline & No comments & $21(16.41 \%)$ \\
\hline \multirow{3}{*}{$\begin{array}{l}\text { Should the law be } \\
\text { strictly enforced? }\end{array}$} & Yes & $26(20.31 \%)$ \\
\hline & No & $97(75.78 \%)$ \\
\hline & No comments & $5(3.91 \%)$ \\
\hline \multirow{3}{*}{$\begin{array}{l}\text { Should the health } \\
\text { care professional be } \\
\text { punished for pre- } \\
\text { natal sex } \\
\text { determination? }\end{array}$} & Yes & $16(12.50 \%)$ \\
\hline & No & $112(87.50 \%)$ \\
\hline & No comments & $0(0 \%)$ \\
\hline \multirow{3}{*}{$\begin{array}{l}\text { Are you willing to } \\
\text { spread awareness } \\
\text { on pre-natal sex } \\
\text { determination? }\end{array}$} & Yes & $104(81.25 \%)$ \\
\hline & No & $12(9.38 \%)$ \\
\hline & No comments & $12(9.38 \%)$ \\
\hline
\end{tabular}

$67.9 \%$ of participants $(n=87)$ were aware of a government act for prevention of sex determination and $84.3 \%$ of the participants $(n=108)$ said that prenatal sex determination is a punishable offence. Most of them had a prior knowledge that both the patients who seek and the doctors who facilitate prenatal sex determination are punishable $(n=92,71.8 \%)$. However, very few were aware of imprisonment as a punishment for violation of Act $(\mathrm{n}=9), 7.03 \%$.

When the participants were assessed for their attitude towards PCPNDT Act, more than half of them responded that prenatal sex determination can be done and prenatal sex determination should not be punishable $(\mathrm{n}=85,66.4$ $\%)(n=82,64.06 \%)$ respectively (Table 4$) .79 .69 \%$ said that if given a chance, they would prefer to know the sex of their unborn child. Male baby was preferred over female baby $(55.47 \%$ and $37.5 \%)$. Two participants were willing to terminate the pregnancy, if they knew it was a female fetus. Majority $(87.5 \%)$ felt that the doctors should not be punished for prenatal sex determination. $81.3 \% \quad(n=104)$ participants were willing to educate people about PCPNDT Act and motivate them against sex determination and sex selective abortions.

\section{DISCUSSION}

Skewed sex ratio has long term social and demographic consequences. In India, the first legal response to control the practice of sex determination and sex selective abortions came into effect in the year 1994 through the introduction of PNDT Act (prenatal diagnostic techniques act), which was amended later in 2004 as preconception and prenatal diagnostic techniques act (PCPNDT). ${ }^{9}$ Though sex selective abortions have been recorded all over India, registration and conviction rates have been less so far. Low registration and conviction rates may be due to several reasons like improper implementation of the act and lack of awareness regarding the Act among the public. Many centres have resorted to actions violating the rules and regulations of the Act without being held or convicted.

In the present study, $82.03 \%$ of the participants knew about the possibility of prenatal sex determination which was higher than the studies conducted at Mumbai, Maharashtra and Bareilly, Uttar Pradesh $73.5 \%$ and $80 \%$ respectively)..$^{10,11}$ Media was the main source of information in this regard. Our observations were similar to the studies conducted at Meerut and Hassan, India. ${ }^{12}$ However, in a study reported from Jammu, friends and relatives were the main source of information. ${ }^{13}$

Majority of our study population $(91.4 \%)$ were aware that ultrasonography is used for sex determination. In addition, many had an opinion that sex determination can be done only at private hospitals. This observation was similar to the results of Mumbai study. ${ }^{9}$ However, in other studies, lower proportion of pregnant women were 
aware of ultrasonography as a technique for sex determination. ${ }^{11,13,14}$

In the current study, $67.9 \%$ of the participants were aware of the Government law against prenatal sex determination and $84.3 \%$ of the participants knew that prenatal sex determination was a punishable offence. $71.8 \%$ were aware that both the person seeking and the person doing sex determination will be punished for the offence. Whereas, in studies conducted at Mumbai and Hassan, only half of the participants knew that prenatal sex determination was a punishable offence. ${ }^{10,13}$

Knowledge among participants on the type of punishment for the offence was low in our study. Majority were of the opinion that levying fine was the only punishment for the person seeking and person doing prenatal sex determination. This observation was similar with the findings of a study conducted in Chandigarh. ${ }^{15}$ Hence public should be enlightened on this aspect of the act.

Over $75 \%$ of the respondents said that if they had a chance, they would prefer to know the gender of their unborn child and male babies were preferred over female babies. However, several studies showed a higher proportion of participant's preference for selective abortion if the sex of fetus is revealed to be a female. ${ }^{11,12,14}$ Our observations were lower than reported, where only two participants agreed that they would opt for termination of pregnancy if the sex of fetus is revealed to be a female. But, it is important to mention, that the number women who didn't want to comment was maximum for this question.

Majority of our participants opined that prenatal sex determination can be done and should not be a made as a punishable act. Many were willing to educate others about PCPNDT act which is similar to the observations of the Mumbai study. ${ }^{9}$

\section{CONCLUSION}

Higher proportion of our study participants knew about the prenatal sex determination and that it was a punishable offence. However, they were not fully aware of the punishment for prenatal sex determination. Still, many preferred to know the sex of unborn child and there was a gender bias towards male babies. A larger proportion also felt that prenatal sex determination can be done and should not be punishable, which means, they are not aware of the current issues related to female sex selective abortions. Hence, pregnant women have to be educated about the penalization for violation of the Act and ethical issues related with female sex selective abortion and feticide. The present research was a hospital based study and our results cannot be extrapolated to other settings. Similar studies in other settings on a larger sample size should be done for in depth understanding of this issue.
Funding: No funding sources

Conflict of interest: None declared

Ethical approval: The study was approved by the Institutional Ethics Committee

\section{REFERENCES}

1. Census of India. Gender composition 2011. Available at http: //censusindia.gov.in /Census_And_You/gender_composition.aspx.

Accessed on 13 March 2016.

2. Kanitkar T, Mistry M. Status of women in India - an interstate comparison. Indian $\mathrm{J}$ Soc Work. 2000;61:381-3.

3. Office of Registrar General and Census Commissioner, India. Population in age group 0-6 years by sex and sex ratio (0-6). Available from: http:// www.censusindia.gov.in/2011-prov-results/ indiaatglance.html. Accessed on 09 April. 2009.

4. Definition of the indicators of population ageing. World Population ageing 1950- 2050. UNFPA Available at http://www.un.org/esa/population /publications/worldageing19502050/pdf/95annexi.pd f. Accessed on 09 April 2009.

5. Deshpande V. Social aspects of declining sex ratio. Indian Journal Radiology. 2012;22:131-2.

6. Handbook of PCPNDT Act and rules with amendments. Ministry of Health and Family Welfare Government of India 2006. Available from: http://www.iria.in/uploadNotices/Handbook_on_PN DT_Act.pdf. Accessed on 12 February 2016.

7. Government of India (GOI). 2003. The Pre-Natal Diagnostic Techniques (Regulation and Prevention of Misuse) Amendment Act. www.xiss. ac.in/RCH/Others/PNDT_Act.pdf. Available at http://mohfw.nic. in/PNDTAmendments.htm. Accessed on 14 April 2012.

8. Declining sex ratio-a matter of concern- India. UNICEF.(cited 2013 october13) Available at http://www.unicef.org/india/child_protection_1360.h tm. Accessed on 15 April 2012.

9. Shindhaye PR, Giri PA, Nagaonkar SN, Shindhaye RR. Study of knowledge and attitude regarding Prenatal Diagnostic Techniques Act among pregnant women at a tertiary care teaching hospital in Mumbai. Journal of Education and Health Promotion. 2012;1:1-4

10. Srivastav S, Kariwal P, Kapilasrami MC. A community based study on awareness and perception on gender discrimination and sex preference among married women (in reproductive age group) in a rural population of district Bareilly Uttar Pradesh. Nat J Comm Med. 2011;2:273-6.

11. Kansal R, Maroof KA, Bansal R, Parashar P. A hospital based study on knowledge, attitude and practice of pregnant women on gender preference, prenatal sex determination and female feticide. Indian J Public Health. 2010;54:209-12.

12. Metri SS, Venktesh GM, Thejeshwari HL. Awareness regarding gender preference and female 
foeticide among teachers in the Hassan District, South India. Journal of clinical and diagnostic research. 2011;5:1430-2.

13. Dhingra R, Manhas S. Perception of rural rajput community of jammu regarding prenatal sex determination tests. Stud Home Com Sci. 2011;5:161-4.

14. Puri S, Bhatia V, Swami HM. Gender preference and awareness regarding sex determination among married women in slums of Chandigarh. Indian $\mathbf{J}$ Community Med. 2007;1:60-2.

15. Vadera BN, Joshi UK, Unadakat SV, Yadav BS, Yadav S. Study on Knowledge, attitude and practices regarding gender preference and female feticide among pregnant women. Indian J Community Med. 2007;32:300-1.

Cite this article as: Sharmila V, Babu TA. Singh D. Knowledge, awareness and attitude about prenatal sex determination, pre- conception and pre-natal diagnostic techniques act among pregnant women in the South Indian union territory of Puducherry. Int J Reprod Contracept Obstet Gynecol 2016;5:3470-4. 